
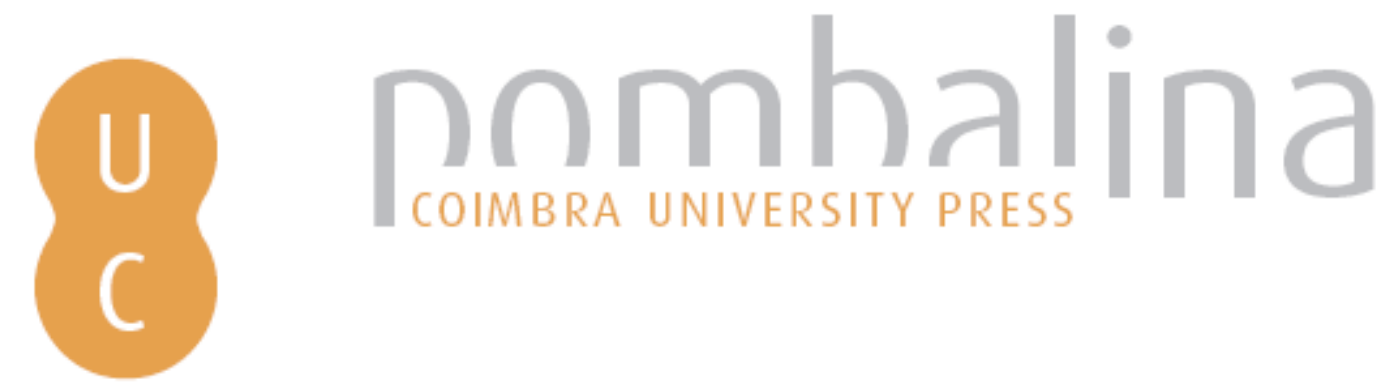

\title{
Risk analysis of LPG tanks at the wildland-urban interface: are regulated safety distances large enough?
}

Autor(es): $\quad$ Pastor, E.; Caballero, D.; Martín, J.; Planas, E.

Publicado por: Imprensa da Universidade de Coimbra

URL

persistente: URI:http://hdl.handle.net/10316.2/44693

DOI: $\quad$ DOI:https://doi.org/10.14195/978-989-26-16-506_176

Accessed : $\quad$ 26-Apr-2023 13:20:58

A navegação consulta e descarregamento dos títulos inseridos nas Bibliotecas Digitais UC Digitalis, UC Pombalina e UC Impactum, pressupõem a aceitação plena e sem reservas dos Termos e Condições de Uso destas Bibliotecas Digitais, disponíveis em https://digitalis.uc.pt/pt-pt/termos.

Conforme exposto nos referidos Termos e Condições de Uso, o descarregamento de títulos de acesso restrito requer uma licença válida de autorização devendo o utilizador aceder ao(s) documento(s) a partir de um endereço de IP da instituição detentora da supramencionada licença.

Ao utilizador é apenas permitido o descarregamento para uso pessoal, pelo que o emprego do(s) título(s) descarregado(s) para outro fim, designadamente comercial, carece de autorização do respetivo autor ou editor da obra.

Na medida em que todas as obras da UC Digitalis se encontram protegidas pelo Código do Direito de Autor e Direitos Conexos e demais legislação aplicável, toda a cópia, parcial ou total, deste documento, nos casos em que é legalmente admitida, deverá conter ou fazer-se acompanhar por este aviso.

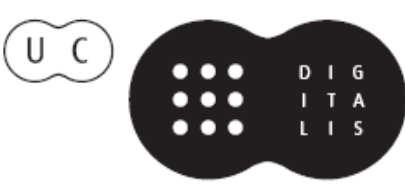




\section{ADVANCES IN}

\section{FOREST FIRE RESEARCH}

\section{8}

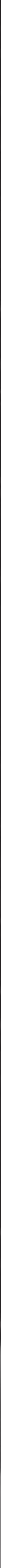


Short contribution - Fire at the Wildland Urban Interface

Risk analysis of LPG tanks at the wildland-urban interface: are regulated safety distances large enough?

\author{
E. Pastor ${ }^{1 *}$; D. Caballero 2 ; J. Martín ${ }^{1}$; E. Planas ${ }^{1}$ \\ ${ }^{I}$ Department of Chemical Engineering, Centre for Technological Risk Studies, Universitat Politècnica de \\ Catalunya·BarcelonaTech, Eduard Maristany 10-14, E-08019 Barcelona, Catalonia, Spain. \\ \{elsa.pastor@upc.edu*,jmartin93upc@gmail.com,eulalia.planas@upc.edu\} \\ ${ }^{2}$ Freelance International Consultant, Consultant: \{davidcaballero@europe.com\}
}

Keywords: WUI fires, WUI microscale, propane tank, domino effect, fire safety.

Forest fires affecting urban and rural communities represent a rising problem throughout the world. They pose tremendous management challenges in terms of civil protection and fire mitigation. These emergencies often exceed fire-fighters capacities due to its multi-risk nature: they usually involve wildfire suppression, structures protection and communities' evacuation and they can even trigger natech-type events when interfacing industrial infrastructure.

The WUI (wildland-urban interface) fire problem is inherently complex, as it is characterized by the interaction of multiple phenomena of diverse nature occurring at different observation scales: the macroscale or landscape scale, the mesoscale or development/settlement scale and the microscale or home/plot scale. It is at the microscale where the specific events that jeopardize residents and assets can be observed and where prevention actions at home-owner level must be undertaken. The WUI microscale is quite often characterized by the presence of all sorts of combustible elements around structures (ground fuels, ornamental vegetation, stored material, etc.) whose hazard is poorly characterized and thus remarkably disregarded by residents.

In this sense, it has to be highlighted the hazard associated with domestic LPG (liquefied petroleum gas) storage tanks, used as energy source for heating, hot water production or cooking in WUI developments. This type of infrastructure can be seriously threaten by a fire nearby, particularly in those cases where negligences or regulatory gaps allow a very close exposure of these tanks to flames coming from nearby fuels.

In countries where this type of domestic LPG infrastructure is currently used, regulations specify, among others, safety distances from the LPG supply unit to vulnerable elements, operation conditions, fire extinguishing systems and other protection measures that have to be taken into account. However, there exist serious deficiencies in the overall regulation framework, particularly in those areas where WUI fires usually occur. For instance, Spanish Standard UNE 60250 (Aenor, 2008) for the set-up, exploitation and manteinance of LPG vessels indicates that for 1 to $5-\mathrm{m}^{3}$ tanks, safety distances should be of $2 \mathrm{~m}$ from the walls of the tank and $3 \mathrm{~m}$ from the service orificies (figure 1). This distances can be reduced by a $50 \%$ for smaller tanks. The Standard also states that the LPG unit should be provided with an enclosure made of metal mesh or other materials with very limited contribution to fire, to avoid manipulation from non qualified personel. Nevertheless, this measure can be ignored in case the tank is located inside a single-family house plot with perimeter elements delimiting the property and preventing the access to outsiders. The Standard has no explicit mention to natural fuels (e.g. ornamental vegetation), usually present at the WUI microscale, that can be located inside the plot and be eventually ignited in case of WUI fire. With these provisions, an scenario of a $5-\mathrm{m}^{3}$ LPG tank closely (i.e. $3 \mathrm{~m}$ ) surrounded by a fence made of a higly flammable ornamental hedgerow (e.g. Cupresus arizonica) is permitted to be set and obviously entails an inherent risk. 


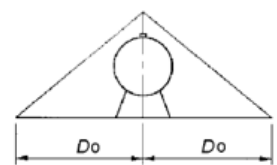

Sección A-A
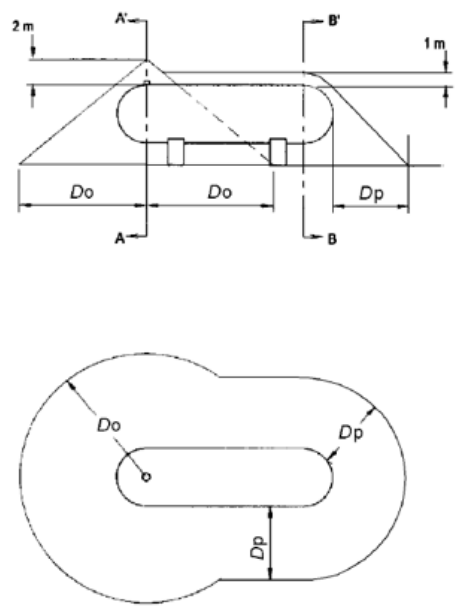

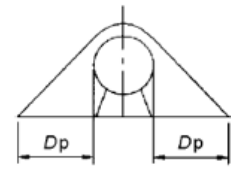

Sección B-B'

Figure 1 - Distances between walls (Dp) and orificies (Do) as indicated by UNE 60250

In recent WUI fire events (e.g. Benitatxell, Spain, 2016; Madeira, Portugal, 2016; Calabassas, California, 2016) these type of infrastructures were dangerously involved in the emergency (figure 2). The lack of an effective safety distance between the LPG tank and the surrounding fuels, provoked undesired overpressure inside the tanks leading to the opening of the safety relief valves. Released gas immediately ignited giving rise to intense jet fires. Although explosions did not occur, the magnitude of the consequences in case of a BLEVE (Boling Liquid Expanding Vapour Explosion)-Fireball event could have been devastating, given the high population and assets density that usually characterize WUI areas.
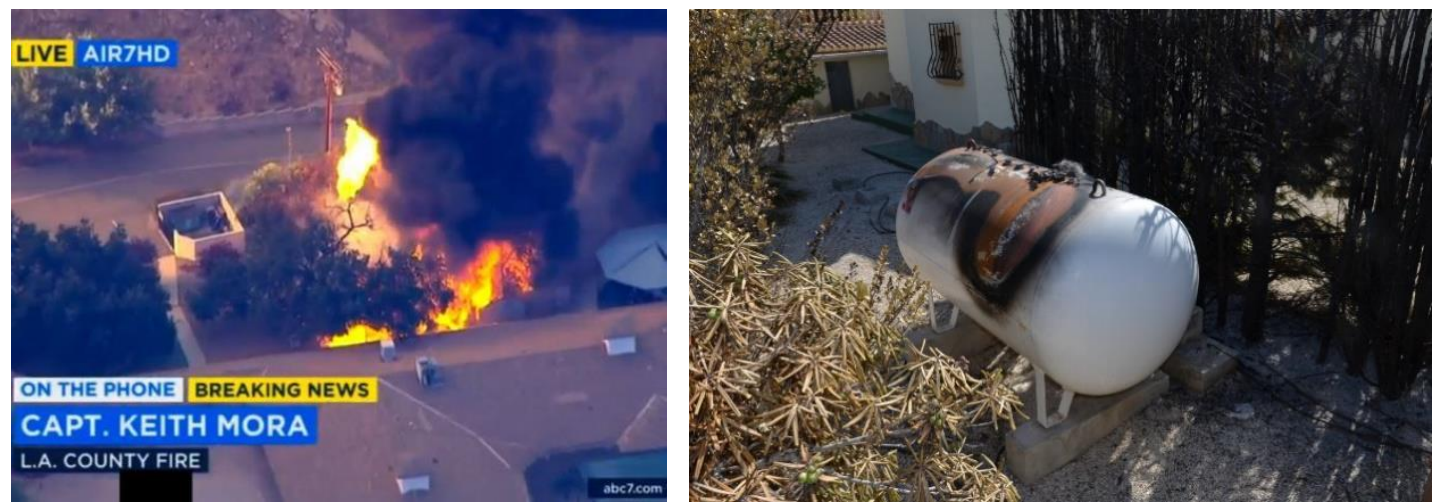

Figure 2 - Left: Calabassas fire (California, 2016). A propane jet fire can be observed at the centre of the image.

Flames from ornamental fuels are close to the tank. LPG infrastructure was inside a kindergarten facility. Right: Domestic LPG tank in Benitatxell (Spain, 2016) damaged by the jet fire. The tank was surrounded by an ornamental hedgerow that ignited by spotting.

The scientific community has already been aware of these type of hazardous scenarios and has started tackling the problem either by an experimental approach (Heymes et al., 2013a) or by physical modelling of the processes involved (Heymes et al., 2013b; Scarponi et al., 2018). However, the scenarios studied have not been reflecting the WUI micro-scale reality. Rather, a less realistic scenario of a distant fully developped crown-fire, which might be developpping at the meso-scale, has been considered as the one threatening an LPG tank.

This paper presents a comprehensive overview by which we identify both technical and scientific needs that have to be addressed to minimize the fire/explosion risk of LPG domestic tanks at the WUI. We analyse the existent regulations in WUI-fire prone countries dealing with domestic LPG services to detect gaps, deficiencies and inconsistencies between countries and regulation bodies. We review the state of the art of experimental and modelling studies dealing with LPG infrastructure risk 
assessment, highlighting the main findings and available methods, and finally, we explore a CFD modelling framework that shall be of help to establish effective safety distances.

\section{References}

Aenor, Asociación Española de Normalización y Certificación. (2008). UNE 60250: instalaciones de almacenamiento de gases licuados del petróleo (GLP) en depósitos fijos para su consumo en instalaciones receptoras. Retrieved from https://temariosformativosprofesionales.files.wordpress.com/2012/11/une_602502008.pdf

Heymes, F., Aprin, L., Birk, A.M., Slangen, P., Jarry, J.B., François, H., Dusserre, G. (2013). An experimental studyof an LPG tank at low filling level heated by a remote wall fire. Journal of Loss Prevention in the Process Industries, 26, 1484-1491.

Heymes, F., Aprin, L., Forestier, S., Slangen, P., Jarry, J.B., François, H., Dusserre, G. (2013). Impact of a distant wildland fire on an LPG tank. Fire Safety Journal, 61, 100-107.

Scarponi, G. E., Landucci, G., Heymes, F., Cozzani, V. (2018). Process Safety and Environmental Protection, 114, 251-270. 